\title{
Differential expression of receptors for advanced glycation end products on monocytes in patients with IDDM
}

\author{
A.Festa ${ }^{1}$, B.Schmölzer ${ }^{2}$, G. Schernthaner ${ }^{1}$, E.J.Menzel ${ }^{2}$ \\ ${ }^{1}$ Department of Medicine 1, Rudolfstiftung Hospital, Vienna, Austria \\ ${ }^{2}$ Department of Immunology, University of Vienna, Austria
}

Summary Accelerated modification of proteins by glucose terminating in the formation of advanced glycation endproducts (AGEs) is one of the main pathogenetic mechanisms of diabetes-associated complications. One pathway by which AGEs may exert their effects is by interaction with specific receptors initially identified on macrophages, monocytes and endothelial cells. As AGE-induced autocrine upregulation of AGE receptors has been observed in vitro, we hypothesized that AGE-binding might be enhanced in diabetic patients to compensate for the elevated levels of circulating AGEs. We therefore examined the expression of AGE-binding sites on peripheral monocytes, serum levels of AGEs and AGE-induced cytokine production in patients with insulin-dependent diabetes mellitus (IDDM) compared to age-matched, healthy control subjects. In patients, AGE-binding capacity was significantly increased and there was only one class of binding sites, as revealed by Scatchard analysis $\left(1.8 \times 10^{5}\right.$ vs $1.4 \times 10^{5}$ binding sites per cell $)$. Affinity of binding was, however, similar $\left(\mathrm{K}_{\mathrm{a}} 1.5 \times 10^{6}\right.$ vs $\left.1.4 \times 10^{6} \mathrm{~mol}^{-1}\right)$. Saturation of binding was reached at $2.0-3.0 \mu \mathrm{mol} / 1$ with AGE-bovine serum albumin (BSA) as ligand. In contrast, cytometry using fluores-

Received: 30 September 1997 and in revised form: 15 January 1998

Corresponding author: Professor E.J.Menzel, Department of Immunology, University of Vienna, Borschkeg. 8A, A-1090 Vienna, Austria

Abbreviations: AGE, Advanced glycation end products; BSA, bovine serum albumin; FACS, fluorescence activated cell sorter; FCS, fetal calf serum; FITC, fluorescein-isothiocyanate; FL, fructosyllysine; HSA, human serum albumin; IDDM, insulin-dependent diabetes mellitus; MFI, mean fluorescence intensity; PBS, phosphate-buffered saline. cein isothiocyanate-labelled AGE-proteins showed no saturability and reversibility of AGE-binding up to $80 \mu \mathrm{mol} / \mathrm{l}$, indicating non-specific binding in this concentration range. Again, this non-specific binding was significantly higher in IDDM patients. In addition, we found much higher levels of circulating AGEs in patients as compared to controls and studied possible functional consequences of increased AGE binding in vitro, monocyte stimulation by AGEs triggering cytokine release to a similar extent in patients and controls, i.e. independently of the AGE-binding capacity. Our finding of an enhanced overall AGEbinding capacity of peripheral monocytes in IDDM could be instrumental in limiting the plasma concentration of AGEs, the non-specific binding coming into play after saturation of specific binding sites by higher plasma AGE-levels. Both binding strategies may act in concert as "damage limitation mechanisms" in the development of AGE-dependent diabetic complications. [Diabetologia (1998) 41: 674-680]

Keywords Insulin-dependent diabetes mellitus, nonenzymatic glycation, monocyte/macrophage, receptor for AGEs, circulating AGEs, cytokines.
Non-enzymatic glycation of proteins and accumulation of Maillard reaction products, so-called advanced glycation endproducts (AGEs), are thought to play an important role in the pathogenesis of diabetic complications [1]. Long-lived macromolecules and proteins, such as collagen, lens crystalline and DNA, are particularly susceptible to AGE modification. Reactive AGEs can directly alter the physical and structural properties of the extracellular matrix, for instance by inducing collagen cross-linking, basement membrane thickening, and covalent trapping of plasma proteins 
such as LDL and IgG [1]. Another pathway, by which AGEs may exert their effects, is via their interactions with specific receptors initially identified on macrophages, monocytes and endothelial cells [1-4]. The co-localisation of AGEs and their receptors at sites of microvascular injury indicates that the subsequent interaction may represent a mechanism for the development of diabetic complications. AGE-receptors with molecular weights of 60 and $90 \mathrm{kDa}$ have been isolated from rat liver and mouse mesangial cells $[2,5]$. Schmidt et al. [3,6] found two AGE-binding proteins, which are displayed on the endothelial cell surface: a $35 \mathrm{kDa}$ polypeptide, belonging to the immunoglobulin superfamily, and an $80 \mathrm{kDa}$ lactoferrin-like polypeptide. The antibodies raised against these proteins inhibited not only the binding of AGE-bovine serum albumin (BSA) to bovine aortic endothelial cells, but also the AGE-induced migration of monocytes [7].

The role of AGE-specific receptors in AGE-processing is, however, controversial. Recent experiments with macrophages from scavenger-receptordeficient mice indicate that scavenger receptors may be more important for the binding, uptake and metabolism of AGE proteins than other putative AGE receptors [8]. In addition, Dobrian et al. [9] showed that LDL preincubated with AGE-BSA is prevalently taken up by macrophages via the scavenger receptor pathway in a non-saturable way while AGE receptors are not participating in this uptake. Early glycation products such as fructosyllysine (FL) have been described to bind specifically to sites on macrophages and monocytes via receptors that are distinct from the AGE-binding membrane proteins [10]. In contrast to others, Shaw and Crabbe [11] found no evidence for a specific AGE-receptor on macrophages. They suggest that non-specific AGE-binding to these cells could be important in limiting the plasma concentration of AGEs in diabetic patients, who show a marked elevation of AGE-levels especially when suffering from end-stage renal disease [12].

In the present study we investigate whether AGEbinding by peripheral monocytes is enhanced in IDDM patients in comparison to age-matched control subjects. We hypothesize that such an increase in AGE-binding would compensate for increased AGE-levels and could be triggered by autocrine cytokine-dependent mechanisms [13-16].

\section{Subjects and methods}

Study subjects and clinical laboratory measurements. Thirty consecutive patients with IDDM, as defined by the National Diabetes Data Group [17] and 30 healthy, age-matched control subjects were recruited from among the patients and the staff of the Department of Medicine 1, Rudolfstiftung Hospital, Vienna. The clinical data of all subjects are summarized in Table 1 . The study was performed in accordance with the principles of the Declaration of Helsinki, 1979.
Table 1. Study population

\begin{tabular}{llll}
\hline & Patients & $\begin{array}{l}\text { Control } \\
\text { subjects }\end{array}$ & $P$-value \\
\hline$n$ (male/female) & $30(18 / 12)$ & $30(22 / 8)$ & \\
Age (years) & $32.8 \pm 2.2$ & $32.6 \pm 1.6$ & NS \\
$\mathrm{HbA}_{1 \mathrm{c}}(\%)$ & $8.8 \pm 0.3$ & $5.2 \pm 0.1$ & $<0.0001$ \\
Mean HbA $_{1 \mathrm{c}}{ }^{\mathrm{a}}(\%)$ & $8.5 \pm 0.3$ & & \\
Fructosamine $(\mu \mathrm{mol} / \mathrm{l})$ & $364 \pm 13$ & $245 \pm 3$ & $<0.0001$ \\
$\begin{array}{l}\text { Disease duration (years) } \\
\text { Retinopathy (yes/no; } n)\end{array}$ & $13.4 \pm 2.0$ & & \\
Incipient nephropathy & $6 / 21$ & & \\
(yes/no; $n$ ) & & & \\
\hline
\end{tabular}

Values are mean \pm SEM

a Mean value of repeated measurements

Evidence of diabetic retinopathy, as obtained by direct ophthalmoscopy in mydriasis, was documented in 9 patients and incipient diabetic nephropathy (urinary albumin excretion rate $>30 \mathrm{mg} / 24 \mathrm{~h}$ ) in 6 patients. Routine blood chemistry was determined by an American Monitor Parallel Analyser (Richmond, VA., USA). $\mathrm{HbA}_{1 \mathrm{c}}$ was measured using a HPLC technique (Biorad, Diamat, Hercules, CA., USA). In 22 patients at least three $\mathrm{HbA}_{1 \mathrm{c}}$ measurements were performed within a period of 1-8 years. The mean value of these repeated $\mathrm{HbA}_{1 \mathrm{c}}$ measurements $\left(\mathrm{M}-\mathrm{HbA}_{1 \mathrm{c}}\right)$ as well as the actual $\mathrm{HbA}_{1 \mathrm{c}}$ value were considered for analysis. Urinary albumin excretion rate was determined by an immunoturbidimetric test (Tina-quant; Boehringer-Mannheim, Mannheim, Germany). All patients had serum creatinine values within the normal range.

Preparation of AGE proteins. Bovine serum albumin (BSA) fraction V (low-endotoxin), RNAse and Glucose 6-phosphate (disodium-salt) were purchased from Sigma (St. Louis, Mo., USA) and human serum albumin (HSA), $99 \%$ purity, from Behringwerke (Marburg, Germany).

We solubilized $20 \mathrm{mg} / \mathrm{ml} \mathrm{BSA}$ (or HSA) in $0.5 \mathrm{~mol} / \mathrm{l} \mathrm{glu}-$ cose 6-phosphate in phosphate-buffered saline (PBS), pH 7.2, and sterilized by sterile filtration with a $0.2 \mu \mathrm{m}$ sterile filter (Corning, N. Y., USA). $10 \mathrm{mg} / \mathrm{ml}$ or $25 \mathrm{mg} / \mathrm{ml}$ RNAse were solubilized in $0.1 \mathrm{~mol} / 1$ glucose 6 -phosphate and all protein/glucose samples were incubated at $37^{\circ} \mathrm{C}$ until fluorescence could be detected, i. e. for 8-10 weeks. AGE proteins were characterized by fluorescence (excitation at $370 \mathrm{~nm}$, emission at $440 \mathrm{~nm}$ ), measured on a RF-551 spectrofluorometric detector (Shimadzu, Vienna, Austria). Results are given in arbitrary fluorescence units (rfu) of protein solutions containing $10 \mathrm{mg}$ / $\mathrm{ml}$ AGE protein. FL content was determined by a commercial fructosamine assay (Hoffmann-LaRoche, Vienna, Austria), degree of AGE-modification by absorption on an anti-AGE column, containing antibody bound to cyanobromide-activated Sepharose (Pharmacia, Uppsala, Sweden).

In this study, AGEs were formed by incubating proteins with glucose 6-phosphate instead of glucose, to obtain AGEproteins in a relatively short incubation time. According to Makita et al. [18] and our own ELISA competition data for anti-AGE RNase antisera (data not shown), AGEs formed in this way are similar to those formed using glucose as glycating agent.

FITC-labelling of AGE-products. AGE proteins were dialysed against $0.25 \mathrm{~mol} / \mathrm{l}$ carbonate buffer, $\mathrm{pH} 9.0$, overnight. We added $0.05 \mathrm{mg}$ fluorescein isothiocyanate (FITC, Sigma) per $\mathrm{mg}$ protein and incubation took place overnight at $4{ }^{\circ} \mathrm{C}$ in the dark. Unbound FITC was removed by dialysis against PBS until no free FITC could be detected in the dialysate. The fluores- 
cence to protein $(\mathrm{F} / \mathrm{P})$ ratio was determined by measuring the extinction at $495 \mathrm{~nm}$ and $280 \mathrm{~nm}$.

Iodination of AGE proteins. AGE-BSA was labelled with ${ }^{125} \mathrm{I}$ using chloramine $\mathrm{T}$ [19] to a specific activity of $190 \mathrm{cpm} / \mathrm{ng}$ protein.

Cell cultures. Peripheral blood mononuclear cells (PMNC) were isolated from fresh, heparinized blood $(50 \mathrm{ml} / \mathrm{subject})$ using density gradient centrifugation on Ficoll-Paque (Pharmacia Biotech LKB, Vienna, Austria). The cells were resuspended in RPMI 1640 Medium + GlutaMAX with $25 \mathrm{mmol} / \mathrm{l}$ HEPES (virus-screened) from Gibco-BRL (Grand Island, N. Y., USA). The medium also contained $10 \%$ sterile-filtered heat-inactivated fetal calf serum (FCS). We added $5 \mathrm{ml}$ penicillin-streptomycin-fungizone $(10000 \mathrm{U} / \mathrm{ml}$ penicillin, $10000 \mu \mathrm{g} /$ $\mathrm{ml}$ streptomycin, $25 \mu \mathrm{g} / \mathrm{ml}$ fungizone) to $500 \mathrm{ml}$ medium. The PMNC suspension was layered into vented tissue culture flasks (No.3111 Falcon/Becton Dickinson, San José, Calif., USA). After 60 min incubation at $37^{\circ} \mathrm{C}$ in humified $5 \% \mathrm{CO}_{2}$-air the flasks were washed three times with sterile PBS to remove non-adherent cells. The flasks were filled with $5 \mathrm{ml}$ RPMI $1640+10 \%$ FCS, now only containing adherent cells. The flasks were placed on ice for $30 \mathrm{~min}$. The vortexed, easily detachable cells were dislodged by carefully scraping with a rubber policeman. More than $80 \%$ of the adhering cells were monocytes, as evidenced by FACS analysis in a FACScan Becton Dickinson flow cytometer at a laser wavelength of $550 \mathrm{~nm}$ using R-phycoerythrin-conjugated monoclonal mouse antibody to CD 14 (Monosan, Uden, The Netherlands). The cells were adjusted to $1.2 \times 10^{6}$ cells per ml in RPMI $1640+10 \%$ FCS. We plated $10.0 \mathrm{ml}$ aliquots of the enriched monocyte suspension into small sterile Falcon tissue culture flasks $(50 \mathrm{ml})$ and incubated them for $2 \mathrm{~h}$ at $37^{\circ} \mathrm{C}$ in $5 \% \mathrm{CO}_{2}$. Approximately $5.0 \times 10^{6}$ cells/flask adhered routinely. The viability of the cells was greater than $98 \%$ as determined by Trypan blue exclusion, the percentage of monocytes was greater than $90 \%$.

\section{Binding studies}

1. FACS studies. $0.5 \mathrm{ml}$ monocyte suspension was precooled on ice. Three, 6, 12, 24 and $48 \mu \mathrm{mol} / 1$ of FITC-AGE-BSA or 2, 5, $10,19,38,77 \mu \mathrm{mol} / 1$ of FITC-AGE-HSA were added and incubated for $2 \mathrm{~h}$ at $4{ }^{\circ} \mathrm{C}$. Under these conditions ligand internalization and degradation are negligible. After the final washing step cells were suspended in $200 \mu \mathrm{l}$ sheath fluid and analysed by flow cytometry (FACS Flow; Becton Dickinson). Monocytes were gated by measuring forward and sideways scattering of an Argon laser. The gated monocyte population was checked with an anti-CD 14 monoclonal antibody. Non-activated lymphocytes did not express binding sites for AGEs. The specificity of binding of long-term glycated BSA was evaluated by competition experiments using AGE-BSA and BSA. Whereas native BSA did not compete for binding, AGE-BSA reduced binding of FITC-AGE-BSA by $10-30 \%$. Dead cells were excluded from analysis using propidium iodide labelling $(1 \mu \mathrm{g} / \mathrm{ml})$. Data were expressed as mean fluorescence intensity (MFI), displayed in the form of single histograms and analysed using Cellquest software (Becton Dickinson) San José, CA., USA).

2. Studies with radiolabelled ligands. The number of specific AGE-receptors per cell as well as the affinity constant of the ligand-receptor interaction was determined by a radio-ligand binding assay. After $20 \mathrm{~h}$ precultivation adherent monolayers were rinsed three times with cold medium containing $10 \%$
FCS and kept at $4{ }^{\circ} \mathrm{C}$ for another 30 min when increasing amounts of ${ }^{125}$ I-labelled AGE-BSA were added. Incubation was again for $2 \mathrm{~h}$ at $4{ }^{\circ} \mathrm{C}$ in the presence or absence of 100 fold excess unlabelled AGE-BSA. Cells were gently shaken during incubation. The radioligand-containing medium was then aspirated, and the cell layer was rinsed three times with $2.0 \mathrm{ml}$ medium followed by three times with PBS. The cells were lysed in $1.0 \mathrm{ml}$ of a solution containing $0.1 \%$ sodium deoxycholate and $0.05 \mathrm{~mol} / \mathrm{l}$ sodium hydroxide and counted in a gamma counter. The amount of protein in each well was measured by the method of Bradford [20]. The results were expressed as counts per min per cell protein per well. Non-specific binding was generally less than $25 \%$ of total binding. Native BSA did not compete for binding of labelled AGE-BSA. The amount of radiolabelled AGE specifically bound was determined and analysed by Scatchard analysis. The small contamination with lymphocytes does not hamper binding data, as non-activated lymphocytes do not express AGE- or FL-binding sites on their cell membranes.

Preparation of polyclonal anti-AGE antibody. To raise an antiAGE antiserum $0.5 \mathrm{ml}$ of $10 \mathrm{mg} / \mathrm{ml}$ or $25 \mathrm{mg} / \mathrm{ml}$ AGE-RNAse in $50 \%$ Freund's incomplete adjuvant was injected s.c. into rabbits (female white New Zealand) at two different sites. Animals were subjected to boosters 2 weeks later with the same amount of AGE-RNAse in $50 \%$ Freund's incomplete adjuvant, followed by additional booster injections every 2 weeks. After the third booster injection blood was collected from the ear vein prior to immunization to determine the anti-AGE antibody titre by ELISA (see below). After 10 weeks of immunization high titres of anti-AGE antibodies could be detected. To eliminate potential antibodies directed against Amadori products, the antiserum was absorbed on short-term glycated bovine serum albumin containing 2-3 moles fructosamine per mole albumin and showing no AGE-specific fluorescence. To this end, antiserum aliquots were passed over a column containing the early glycation product bound to BrCN-Sepharose (Pharmacia, Uppsala, Sweden). Control experiments using short-term glycated BSA as solid phase antigen in a non-competitive ELISA revealed no significant binding of the antiserum in dilution experiments using serial dilutions in the range $10^{-2}$ to $10^{-6}$ [18]. Even BSA glycated for 3 weeks which already showed significant AGE-specific fluorescence did not react with the antibody. To further characterise our antiAGE-RNase antiserum we performed ligand inhibition experiments in a competitive ELISA (solid phase antigen: AGE-RNA or AGE-HSA) using BSA, short-term glycated BSA (1-3 weeks) and carboxymethyllysine, an example of a known AGE structure, as inhibitors up to micromolar inhibitor concentrations. No significant inhibition could be found. Potential specificity against AGE-derived cross-links was determined by using polymeric albumin obtained by long-term glycation ( 6 months using $0.5 \mathrm{~mol} / \mathrm{l}$ glucose) for coating in the non-competitive or as inhibitor in the competitive ELISA procedure. This AGE-BSA contained polymers up to hexameric albumin, as revealed by SDS-polyacrylamide gel electrophoresis on a gradient gel. The main bulk of monomeric AGEBSA was separated from polymers by molecular sieve chromatography. The anti-AGE antibody reacted significantly more strongly with this polymeric AGE-BSA than with monomeric AGE-BSA indicating some specificity against AGE-derived cross-links (data not shown). In gel diffusion experiments, the anti-AGE serum precipitated AGE-HSA, AGE-BSA and polymeric AGE-BSA, but not HSA and BSA.

AGE-ELISA procedure. Maxisorb plates (NUNC, Kastrup, Denmark) were incubated for $1 \mathrm{~h}$ with $0.05 \mathrm{mg} / \mathrm{ml}$ AGE-BSA 
or AGE-HSA at $37{ }^{\circ} \mathrm{C}$ and 3 days at $4{ }^{\circ} \mathrm{C}$. After washing three times with PBS containing $0.1 \%$ Tween, wells were incubated with PBS containing $0.02 \% \mathrm{NaN}_{3}$ and $0.4 \%$ BSA for $2 \mathrm{~h}$ at $4{ }^{\circ} \mathrm{C}$ to block unspecific binding. Serum samples were diluted 1:2 with anti-AGE-antibodies, diluted 1:500 in PBS containing $0.4 \% \mathrm{BSA}$, in glass tubes and incubated for $1 \mathrm{~h}$ at $37^{\circ} \mathrm{C}$ in a water bath followed by $16 \mathrm{~h}$ incubation at $4{ }^{\circ} \mathrm{C}$. After washing the wells 3 times $200 \mu$ l aliquots were placed into each AGEcoated well. Incubation time was $1 \mathrm{~h}$ at $37^{\circ} \mathrm{C}$ and $0.5 \mathrm{~h}$ at $4{ }^{\circ} \mathrm{C}$. After washing 3 times $200 \mu \mathrm{l}$ of 1:1000 diluted anti-rabbit Ig, horseradish peroxidase linked whole antibody from donkey (Amersham, Life Science) was added and incubated for $1 \mathrm{~h}$ at $37^{\circ} \mathrm{C}$. After washing 3 times $200 \mu \mathrm{l}$ 2,2'-Azinobis (3-ethyl benzthiazoline-sulfonic acid) (ABTS) (Boehringer Mannheim) was added and the reaction was carried out for $10 \mathrm{~min}$ at room temperature. The reaction was terminated by adding $50 \mu \mathrm{l}$ oxalic acid and the absorbance at $495 \mathrm{~nm}$ was read on a microplate reader. A standard curve using AGE-HSA was obtained in the range from $0.3 \mathrm{ng} / \mathrm{ml}-100 \mu \mathrm{g} / \mathrm{ml}$. A concentration of $3 \mathrm{ng} / \mathrm{ml}$ AGE-HSA inhibited antiserum binding to AGEHSA coated wells by $50 \%, 6 \mu \mathrm{g} / \mathrm{ml}$ by $95 \%$. Anti-AGE antibody binding to the solid phase AGE-protein was non-specifically reduced by $30 \%$ in the presence of $1: 2$ diluted control human serum as compared to 1:10 diluted serum or buffer alone. Therefore, the standard curve was prepared in the presence of 1:2 diluted normal serum.

Cytokine production by monocytes. Adherent enriched monocytes from patients and control subjects $\left(0.2 \times 10^{6} /\right.$ well; $>90 \%$ ) were incubated in 96-well Falcon tissue culture plates in medium for $16 \mathrm{~h}$ in the presence or absence of $12 \mu \mathrm{mol} / 1$ AGE-BSA. Preliminary investigations had shown that at this concentration of AGE-BSA maximal cytokine production was obtained. Interleukin (IL-6 and IL-8) concentrations were determined in the supernatants after centrifugation at $800 \mathrm{~g}$ for $10 \mathrm{~min}$ in the cold using commercial ELISAs (Medgenix, Fleurus, Belgium).

Endotoxin test. After dialysis to remove glucose 6-phosphate, AGE-proteins were tested for endotoxin using a commercial chromogenic Limulus amoebocyte lysate (LAL) method (Coatest Endotoxin; Endosafe, Charleston, S. C., USA). Possible interference due to $\beta$-D-glucans (LAL-reactive glucans, [21]) originating from dialysis membranes was checked with endotoxin-specific buffer solution (Endosafe). Maximal endotoxin contamination of AGE-proteins thus determined was found to be below $100 \mathrm{pg} / \mathrm{ml}$.

Statistical analysis. Analysis was performed using SAS statistical software (SAS Inst. Inc., Cary, N. C., USA). Results are given as mean values \pm SEM. Differences between groups were calculated by two tailed Student's $t$-test and chi square-test. For non-parametric analysis the Kruskal-Wallis test was used. Correlation analysis was performed using Pearson's correlation coefficient. $p$ less than 0.05 was considered statistically significant.

\section{Results}

AGE proteins. AGE-BSA glycation was terminated after 8-10 weeks at a fluorescence of 3975 relative fluorescence units (rfu), AGE-HSA at $2000 \mathrm{rfu}$, $10 \mathrm{mg} / \mathrm{ml} \mathrm{RNAse}$ at $2630 \mathrm{rfu}$ and $25 \mathrm{mg} / \mathrm{ml} \mathrm{RNAse}$ at $5280 \mathrm{rfu}$. After FITC-labelling the F/P ratio was 4.8 for AGE-BSA and 6.3 for AGE-HSA. FL-con-

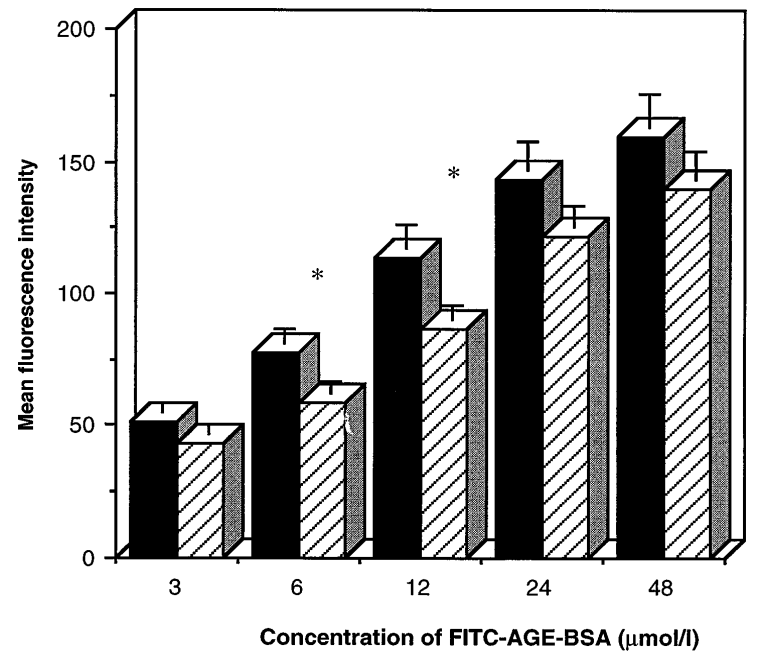

Fig. 1. FACS analysis with increasing amounts of FITC-AGEBSA using monocytes of patients, $n=30(\square)$ and control subjects, $n=30(\mathbb{Z}) ;{ }^{*} \quad p<0.01$

tent was determined by the fructosamine-assay and found to be $6.6 \mathrm{~mol}$ FL per mol AGE-BSA and 4.7 for AGE-HSA.

Immune absorption on an anti-AGE antibody column (Anti-AGE coupled to Cyanobrom-Sepharose) revealed that more than $98 \%$ of the applied AGEproteins remained on the column, indicating a high degree of AGE-modification. Unmodified proteins were not retained.

\section{Binding studies}

a) FACS analysis. In patients and control subjects a linear increase of the mean fluorescence intensity (MFI) with increasing concentrations of FITCAGE-BSA (Fig.1) and FITC-AGE-HSA (data not shown for this ligand) could be demonstrated. This finding indicates a dose-dependent increase in AGE-binding, i.e. AGE-molecule density on the cell surface. In contrast, gated lymphocytes did not show significant binding of labelled AGE (data not shown). The MFI was increased in patients compared to control subjects: $78 \pm 6$ vs $59 \pm 4(p<0.01)$ at a concentration of $6 \mu \mathrm{mol} / \mathrm{l}$ AGE-BSA and $113 \pm 9$ vs $86 \pm 6(p<0.01)$ at a concentration of $12 \mu \mathrm{mol} / 1$ AGE-BSA. At these two concentrations the MFI also significantly correlated with the actual $\mathrm{HbA}_{1 \mathrm{c}}$ value $(r=0.31, p<0.02$ at $6 \mu \mathrm{mol} / \mathrm{l}$ AGE-BSA and $r=0.28, p<0.03$ at $12 \mu \mathrm{mol} / 1$ AGE-BSA) in the entire study population $(n=60)$. Mean percentages of monocytes expressing detectable amounts of AGEs ("percent positive cells") were similar in patients and control subjects and amounted to at least $95 \%$ in the AGE-concentration range $10-80 \mu \mathrm{mol} / 1$. In the competitive binding assays using a tenfold molar excess of unlabelled AGE-protein we found only 


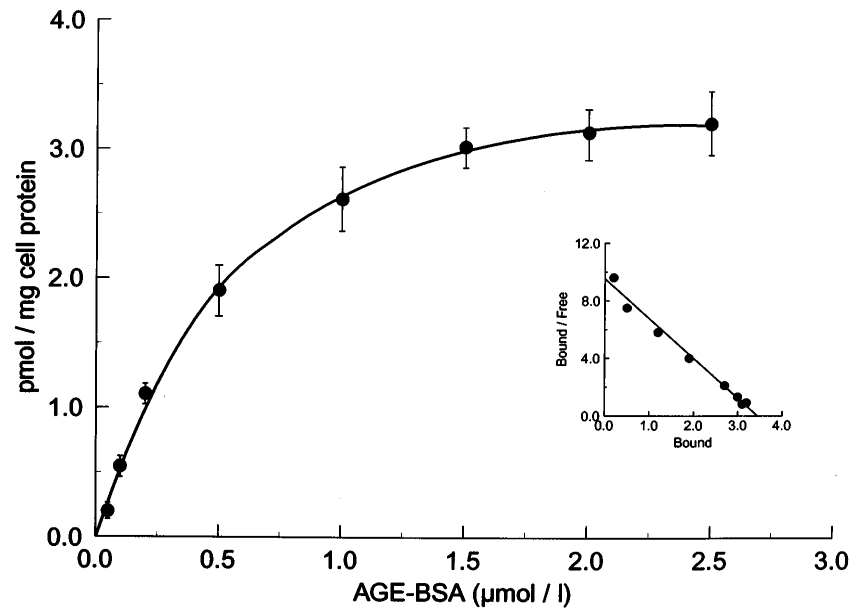

Fig. 2. Binding study (Scatchard analysis) with increasing amounts of ${ }^{125}$ I labelled AGE-BSA using monocytes of a single IDDM patient. The units on the $x$ axis of the insert are pmol $\times \mathrm{mg}^{-1}$ cell protein and on the $y$ axis pmol $\times \mathrm{mg}^{-1} \times$ $\mathrm{nmol}^{-1}$

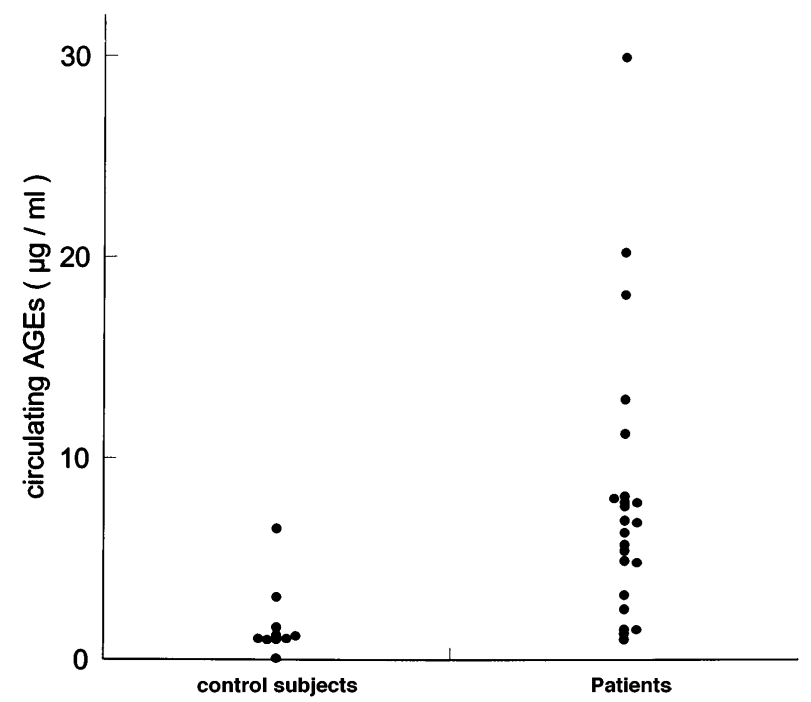

Fig.3. Results of the anti-AGE ELISA in patients $(n=30)$ and control subjects $(n=30)$, depicted as dot plots. Only positive results are shown ( $n=23$ patients; $n=10$ control subjects)

$17-30 \%$ inhibition of FITC-AGE-protein binding, suggesting a predominantly non-specific binding mode. A 100-fold excess of unlabelled AGE-BSA, as usually used in inhibition assays, cannot be achieved in the concentration range tested by FACS analysis. Correlation analysis showed no significant relationship between degree of binding and age, diabetes duration and actual blood glucose. Subgroup analysis revealed a lower MFI in patients with good metabolic long-term control (mean $\mathrm{HbA}_{1 \mathrm{c}} \leq 7.5 \%$; $n=5)$ compared to patients with a mean $\mathrm{HbA}_{1 \mathrm{c}}>7.5 \% \quad(n=17)$ : the MFI was $79 \pm 12$ vs $123 \pm 14(p<0.05)$ at a concentration of $12 \mu \mathrm{mol} / 1$ AGE-BSA, $102 \pm 15$ vs $153 \pm 16(p<0.05)$ at a con-
Table 2. Scatchard analysis: number/cell $(\mathrm{R})$ and binding affinity $\left(\mathrm{K}_{\mathrm{a}}\right)$ for ${ }^{125} \mathrm{I}$-AGE-BSA of AGE-receptors on monocytes of IDDM patients $(n=17)$ and control subjects $(n=10)$

\begin{tabular}{lllllll}
\hline & $\begin{array}{l}\mathrm{R}\left(\times 10^{5}\right) \\
\text { per cell }\end{array}$ & $p$ & $\begin{array}{l}\mathrm{K}_{\mathrm{a}} \\
\left(\times 10^{6} \mathrm{~mol}^{-1}\right)\end{array}$ & $p$ & MFI & $p$ \\
\hline Patients & $1.83 \pm 0.09$ & $1.52 \pm 0.10$ & $\mathrm{NS}$ & $123 \pm 14$ & \\
& $<0.01$ & & & $<0.05$ \\
Control & $1.39 \pm 0.08$ & & $1.43 \pm 0.17$ & & $75 \pm 4$ & \\
subjects & & & & & & \\
\hline
\end{tabular}

Values are mean \pm SEM

MFI, Mean fluorescence intensity (FACS analysis)

centration of $24 \mu \mathrm{mol} / \mathrm{l}$ AGE-BSA and $116 \pm 11 \mathrm{vs}$ $179 \pm 20(p<0.01)$ at a concentration of $48 \mu \mathrm{mol} / 1$ AGE-BSA. No differences in AGE-binding could be detected between patients with or without microvascular complications (data not shown).

b) Scatchard analysis. Binding studies with ${ }^{125} \mathrm{I}-$ AGE-BSA were performed in 27 of the FACS-analysed subjects (control subjects, $n=10$; patients, $n=17) .{ }^{125}$ I-BSA binding followed typical saturation kinetics as shown in Figure 2 for one patient. Scatchard analysis of the binding data demonstrated a single class of binding sites in patients and control subjects. Half-maximal binding was usually obtained at around $0.5 \mu \mathrm{mol} / \mathrm{l}$. In all patients and control subjects tested, binding of radioactively labelled BSA was strongly competed by excess unlabelled BSA (75-91\% inhibition), indicating the specific nature of binding.

As shown in Table 2 the number of AGE receptors per cell was significantly higher in IDDM patients as compared to the control subjects, while the mean binding affinity as represented by the affinity constant $\mathrm{K}_{\mathrm{a}}$ was increased, although not significantly. Table 2 also indicates that binding of FITC-labelled AGEBSA as demonstrated by cytometry (MFI values) was significantly enhanced in these 17 IDDM patients.

Cytokines. To determine whether monocytes from IDDM patients with poor long-term metabolic control (mean $\mathrm{HbA}_{1 \mathrm{c}}>7.5 \%$ ) produce enhanced amounts of cytokines upon stimulation with AGEprotein as compared to cells from healthy individuals, who clearly have lower numbers of AGE-binding proteins on their monocytes, supernatants of overnight monocyte cultures were analysed for IL- 6 and IL-8 concentration. There was no difference between patients and control subjects regarding cytokine production, irrespective of whether cells had been AGE-activated or not (Table 3).

$A G E$-ELISA. Circulating AGEs were found significantly more often in patients than in control subjects (23 patients [77\%] vs 10 control subjects [33\%]; $p<0.002)$. Levels of circulating AGEs were significantly higher in patients than in control subjects 
Table 3. Cytokine production of diabetic $(n=17)$ and control $(n=10)$ monocytes after activation by $12 \mu \mathrm{mol} / 1$ AGE-BSA or without activation

\begin{tabular}{lllll}
\hline Activation & IL-6 $(\mathrm{ng} / \mathrm{ml})$ & \multicolumn{3}{l}{ IL-8 $(\mathrm{ng} / \mathrm{ml})$} \\
\cline { 2 - 5 } & Patients & $\begin{array}{l}\text { Control } \\
\text { subjects }\end{array}$ & Patients & $\begin{array}{l}\text { Control } \\
\text { subjects }\end{array}$ \\
\hline No & $20.7 \pm 0.8$ & $18.7 \pm 1.6$ & $32.6 \pm 1.0$ & $27.5 \pm 0.9$ \\
Yes & $31.4 \pm 1.0^{\mathrm{a}}$ & $28.2 \pm 1.8^{\mathrm{a}}$ & $56.8 \pm 1.7^{\mathrm{a}}$ & $59.2 \pm 2.2^{\mathrm{a}}$ \\
\hline
\end{tabular}

Values are mean \pm SEM

No significant differences between patients and controls

${ }^{\mathrm{a}} p<0.001$ activated vs unactivated

Table 4. Clinical characteristics of patients with $(\mathrm{AGE}+)$ and without (AGE -) circulating AGEs

\begin{tabular}{llll}
\hline & AGE + & AGE - & $P$-value \\
\hline Number $(n)$ & 23 & \multicolumn{1}{l}{7} & \\
Age (years) & $30.2 \pm 2.3$ & $41.1 \pm 4.1$ & $<0.05$ \\
Diabetes duration (years) & $10.3 \pm 2.2$ & $14.3 \pm 4.0$ & $\mathrm{NS}$ \\
HbA $_{1 \mathrm{c}}(\%)$ & $9.0 \pm 0.4$ & $8.2 \pm 0.5$ & $\mathrm{NS}$ \\
Mean HbA $_{1 \mathrm{c}}(\%)^{\text {a }}$ & $8.6 \pm 0.4$ & $8.3 \pm 0.4$ & $\mathrm{NS}$ \\
Retinopathy $($ yes/no; $n)$ & $7 / 16$ & $2 / 5$ & $\mathrm{NS}$ \\
Incipient nephropathy & $4 / 19$ & $2 / 5$ & $\mathrm{NS}$ \\
(yes/no; $n$ ) & & &
\end{tabular}

Values are mean \pm SEM

a Mean value of repeated measurements

$(7.97 \pm 1.45$ vs $1.80 \pm 0.58 \mu \mathrm{g} / \mathrm{ml}, p<0.0005$, using Kruskal-Wallis test; Fig. 3). The mean age of patients with circulating AGEs was significantly lower than that of patients without circulating AGEs (Table 4), whereas no such difference could be detected in the control population $(31.8 \pm 2.7$ years vs $33.0 \pm 4.3$, N.S.). In the entire study population $(n=60)$ circulating AGEs correlated with parameters of glycaemic control (blood glucose: $r=0.37, p<0.005$; fructosamine: $r=0.36, p<0.005$; $\mathrm{HbA}_{1 \mathrm{c}}: r=0.47, p<0.0005$ ). No correlation could be detected, however, between circulating AGEs and AGE-binding by monocytes.

\section{Discussion}

In the present study, we compared the AGE-binding capacity of monocytes in IDDM patients with that in healthy individuals. AGE-binding was significantly higher in the diabetic group, as verified both by cytometry and binding studies with ${ }^{125}$ I-BSA. Only these latter experiments, however, demonstrate that the binding of AGE-BSA is specific, i.e. reversible and saturable. Scatchard analysis revealed a single class of binding sites. The increased specific binding must be due to the significantly increased membrane density of binding sites, because the affinity of the AGE binding as represented by the apparent affinity constant, $\mathrm{K}_{\mathrm{a}}$, did not differ significantly between patients and control subjects. Receptor number per cell as well as $\mathrm{K}_{\mathrm{a}}$ values roughly correspond to binding affi- nity data obtained by others using freshly isolated unactivated monocytes from healthy individuals after 1-2 days preincubation [16]. We interpret these findings as an increased expression of receptors for AGEs on monocytes of diabetic patients.

In contrast, cytometry showed binding characteristics which must be interpreted as non-specific. Such non-specific binding outweighing by far possible specific receptor-mediated interactions has been described by Shaw et al. [11] for iodinated, not FITC-labelled AGE-BSA. In keeping with these and our present results, Dobrian et al. [9] found that AGE-modified LDL is prevalently taken up by macrophages in a non-saturable manner. We hypothesize therefore, that after saturation of the specific AGE-binding sites in a narrow AGE-concentration range $(0-3 \mu \mathrm{mol} / \mathrm{l})$, which cannot be recognized as a region of specific binding by cytometry (only 5-20\% classified as "positive cells" by FACS analysis), a non-specific AGEbinding range is encountered at higher ligand concentrations (above $5 \mu \mathrm{mol} / \mathrm{l}$ ). The irreversible component of this binding could result from direct covalent bond formation with cell membrane structures by the highly reactive AGE moieties, such as shown in vitro for lipoprotein [22]. These non-specific binding activities of monocytes/macrophages reflect the presence of a much higher number of binding sites than the specific activities and enable them to adsorb high amounts of AGEs thereby efficiently limiting the concentration of circulating AGEs. Although not saturable and of probably lower binding avidity than specific binding, non-specific binding likewise depends on binding site density, which was also found by us to be significantly higher in IDDM monocytes. Therefore, peripheral IDDM monocytes may accommodate significantly higher amounts of circulating AGEs per cell, especially at elevated AGE plasma levels, than their control counterparts circulating in healthy individuals, underlining the physiological importance also of the "nonspecific" binding compartment. The fact that nonspecific binding does not engender endocytosis and subsequent intracellular degradation may represent a significant advantage over specific binding of AGEs, because release of small AGE-peptides as a consequence of incomplete AGE-degradation is avoided. The reason for the increased non-specific binding of AGEs by peripheral monocytes from IDDM patients is unknown, but may be associated with the general decreased expression of surface molecules such as Lymphocyte function - associated antigen-1 (LFA1), Intercellular adhesion molecule-1 (ICAM-1) and Human Leukocyte antigen-DR (HLA-DR) on IDDM monocytes [23], which could support non-specific interaction with AGE ligands.

In vitro studies [16] indicate that macrophages utilize cytokines induced by AGE-protein uptake in an autocrine manner to regulate the AGE-receptor function. However, in our hands, the increased pre- 
sence of AGE-binding proteins on diabetic monocytes did not result in an enhanced cytokine production after activation by AGEs. Furthermore, no correlation between circulating AGEs and parameters of receptor expression could be shown in our study, although AGE levels were elevated more than fourfold in IDDM patients as compared to control subjects and the frequency of demonstrable circulating AGEs was significantly higher in accordance to earlier studies [12, 18, 24, 25].

In summary, we noted increased AGE levels in IDDM patients although their monocyte population is endowed with a significantly increased AGE-eliminating capacity both via specific and non-specific binding. One of the reasons for this apparent discrepancy may reside in the putative "remodelling" of AGEs by monocytes/macrophages through specific uptake and partial intracellular degradation followed by the release of small and highly reactive AGE-peptides into the circulation.

Acknowledgements. We gratefully acknowledge Ms. C.Zangerle for laboratory and technical assistance. This work was supported by the Austrian Research Funds Project No.10918MED and by the Nationalbank Jubiläumsfonds No. 5690.

\section{References}

1. Brownlee M, Cerami A, Vlassara H (1988) Advanced glycosylation end products in tissue and the biochemical basis of diabetic complications. N Engl J Med 318: 1315-1321

2. Yang Z, Makita Z, Horii Y et al. (1991) Two novel rat liver membrane proteins that bind advanced glycosylation endproducts: relationship to macrophage receptor for glucosemodified proteins. J Exp Med 174: 515-524

3. Schmidt AM, Hori O, Brett J, Yan SD, Wautier JL, Stern D (1994) Cellular receptors for advanced glycation end products. Implications for induction of oxidant stress and cellular dysfunction in the pathogenesis of vascular lesions. Arterioscler Thromb 14: 1521-1528

4. Esposito C, Gerlach H, Brett J, Stern D, Vlassara H (1989) Endothelial receptor-mediated binding of glucose-modified albumin is associated with increased monolayer permeability and modulation of cell surface coagulant properties. J Exp Med 170: 1387-1407

5. Doi T, Vlassara H, Kirstein M, Yamada Y, Striker GE, Striker LJ (1992) Receptor-specific increase in extracellular matrix production in mouse mesangial cells by advanced glycosylation end products is mediated via platelet-derived growth factor. Proc Natl Acad Sci 89: 2873-2877

6. Schmidt AM, Vianna M, Gerlach M et al. (1992) Isolation and characterization of two binding proteins for advanced glycosylation end products from bovine lung which are present on the endothelial cell surface. J Biol Chem 267: 14987-14997

7. Schmidt AM, Yan SD, Brett J, Mora R, Nowygrod R, Stern D (1993) Regulation of human mononuclear phagocyte migration by cell surface-binding proteins for advanced glycation end products. J Clin Invest 91: 2155-2168

8. Suzuki H, Kurihara Y, Takeya M et al. (1997) A role for macrophage scavenger receptors in atherosclerosis and susceptibility to infection. Nature 386: 292-296
9. Dobrian A, Vadim L, Tirziu D, Simionescu M (1996) Increased macrophage uptake of irreversibly glycated albumin modified - low density lipoproteins of normal and diabetic subjects is mediated by nonsaturable mechanisms. Biochim Biophys Acta 1317: 5-14

10. Brandt R, Landmesser C, Vogt L et al. (1996) Differential expression of fructosyllysine-specific receptors on monocytes and macrophages and possible pathophysiological significance. Diabetologia 39: 1140-1147

11. Shaw SM, Crabbe MJC (1994) Non-specific binding of advanced glycosylation end-products to macrophages outweighs specific receptor-mediated interactions. Biochem J 304: 121-129

12. Makita Z, Radoff S, Rayfield EJ et al. (1991) Advanced glycosylation endproducts in patients with diabetic nephropathy. N Engl J Med 325: 836-842

13. Vlassara H, Brownlee M, Manogue KR, Dinarello CA, Pasagian A (1988) Cachectin/TNF and IL-1 induced by glucose-modified proteins: role in normal tissue remodeling. Science 240: 1546-1548

14. Kirstein M, Brett J, Radoff S, Ogawa S, Stern D, Vlassara H (1990) Advanced protein glycosylation induces transendothelial human monocyte chemotaxis and secretion of platelet-derived growth factor: role in vascular disease of diabetes and aging. Proc Natl Acad Sci 87: 9010-9014

15. Kirstein M, Aston C, Hintz R, Vlassara H (1992) Receptorspecific induction of insulin-like growth factor I in human monocytes by advanced glycosylation end product-modified proteins. J Clin Invest 90: 439-446

16. Vlassara H, Moldawer L, Chan B (1989) Macrophage/ monocyte receptor for nonenzymatically glycosylated protein is upregulated by cachectin/tumor necrosis factor. $\mathbf{J}$ Clin Invest 84: 1813-1820

17. National Diabetes Data Group (1979) Classification of diabetes mellitus and other categories of glucose intolerance. Diabetes 28: 1039-1057

18. Makita Z, Vlassara H, Cerami A, Bucala R (1992) Immunochemical detection of advanced glycosylation end products in vivo. J Biol Chem 267: 5133-5138

19. McConahey PJ, Dixon FJ (1966) A method of trace iodination of proteins for immunological studies. Int Arch Allergy 29: 185-189

20. Bradford M (1976) A rapid and sensitive method for the quantitation of microgram quantities of protein utilizing the principles of protein-dye binding. Anal Biochem 72: 248-254

21. Morita T (1981) A new (1-3)- $\beta$-D-glucan-mediated coagulation pathway found in Limulus amoebocytes. FEBS Lett 129: 318-321

22. Gugliucci A, Bendayan M (1996) Renal fate of circulating advanced glycated end products (AGE): evidence for reabsorption and catabolism of AGE-peptides by renal proximal cells. Diabetologia 39: 149-160

23. Martin S, Rothe H, Tschöpe D, Schwippert B, Kolb H (1991) Decreased expression of adhesion molecules on monocytes in recent onset IDDM. Immunology 73: 123-125

24. Berg TJ, Dahl-Jorgensen KD, Torjesen PA, Hanssen KF (1997) Increased serum levels of advanced glycation end products (AGEs) in children and adolescents with IDDM. Diabetes Care 20: 1006-1008

25. Beisswenger PJ, Makita Z, Curphey TJ et al. (1995) Formation of immunochemical advanced glycosylation end products precedes and correlates with early manifestations of renal and retinal disease in diabetes. Diabetes 4: 824-829 